Aneta Arkuszewska

Uniwersytet Rzeszowski

\title{
UCHYLENIE POSTANOWIENIA O UZNANIU ZA ZMAR EEGO W TRYBIE PRZYŚPIESZONYM
}

Nieodłącznym elementem życia, a w właściwie jego konsekwencją jest śmierć. Śmierć i życie postrzegane mogą być w aspekcie filozoficznym, socjologicznym, psychologicznym, ale i prawnym. W ujęciu prawnym pojęcia te obejmują najbardziej przyziemny ich wymiar. Co istotne, nie zawsze zakończenie życia człowieka $\mathrm{w}$ sensie prawnym jest tożsame $\mathrm{z}$ jego śmiercią w sensie biologicznym. Przykładem może być fakt zaginięcia osoby, a w konsekwencji uznanie jej za zmarłą przez organ sądowy, gdy w rzeczywistości osoba fizyczna żyje, lecz brak o niej jakiejkolwiek wiadomości.

I. Celem postępowania o uznaniu za zmarłego jest uznanie, że osoba fizyczna, która zaginęła i która prawdopodobnie nie żyje - zmarła - tak więc celem jest uregulowanie sytuacji prawnej osoby, która zaginęła, ale i innych podmiotów, powstałej na skutek zaginięcia danej osoby. Wprowadzenie pewności w sferę prawną podmiotów związanych z zaginionym następuje przez wydanie orzeczenia wywołującego takie skutki prawne, jak gdyby zaginiony zmarł w chwili oznaczonej w postanowieniu jako chwila śmierci. ${ }^{1} \mathrm{~W}$ postępowaniu tym dochodzi do wydania postanowienia powodującego zakończenie zdolności prawnej osoby fizycznej i jest konieczne dla uporządkowania stosunków prawnych podmiotów związanych $\mathrm{z}$ uznanym za zmarłego. Postanowienie sądu wydane $\mathrm{w}$ tym przedmiocie ma charakter konstytutywny - tworzący nowy stan prawny ${ }^{2}$ i jednocześnie stwarza

1 Por. W. Siedlecki, [w:] System prawa procesowego cywilnego. Postępowanie rozpoznawcze przed sądami pierwszej instancji, t. II, Z. Resich (red.), Wrocław-Warszawa-Kraków-Gdańsk-Łódź 1987, s. 665; idem, Zarys postępowania cywilnego, Warszawa 1968, s. 412; B. Dobrzański, [w:] B. Dobrzański, M. Lisiewski, Z. Resich, W. Siedlecki, Kodeks postępowania cywilnego. Komentarz, Z. Resich, W. Siedlecki (red.), Warszawa 1969, s. 796. Orzeczenia konstytutywne tworzą lub przekształcają prawo, stosunek prawny lub sytuację prawną z chwilą uprawomocnienia się orzeczenia (ex nunc) jak i mocą wsteczną (ex tunc) - K. Korzan, Istota i charakter orzeczeń wydawanych w postępowaniu cywilnym (studium teoretyczne), [w:] Studia z prawa postępowania cywilnego. Księga pamiątkowa ku czci Z. Resicha, T. Ereciński, M. Jędrzejewska (red.), Warszawa 1985, s. 160; Z. Resich, [w:] J. Jodłowski, Z. Resich, Postępowanie cywilne, Warszawa 1979, s. 384. 
domniemanie, że zaginiony zmarł w chwili oznaczonej jako chwila jego śmieci określona w tym orzeczeniu. ${ }^{3}$

Wskazane domniemanie może być jednak obalone w postępowaniu o uchylenie prawomocnego postanowienia o uznaniu za zmarłego, które może być dwojakiego rodzaju - po przeprowadzeniu postępowania dowodowego i bez takiego postępowania, w trybie - można by go nazwać - przyśpieszonym.

Postępowanie o uznanie za zmarłego oraz uchylające postanowienie o uznaniu za zmarłego odbywają się w trybie nieprocesowym - niespornym, a unormowane są w art. 526-534 k.p.c. oraz art. 539-543 k.p.c. W kwestiach nieuregulowanych $\mathrm{w}$ tych przepisach zastosowanie mają $\mathrm{w}$ pierwszej kolejności przepisy ogólne o postępowaniu nieprocesowym (art. 506-525 k.p.c.), a następnie przepisy o trybie procesowym (art. $13 \S 2$ k.p.c.). Z tym, że art. $13 \S 2$ k.p.c. obejmujący odpowiednie stosowanie przepisów o procesie do innych rodzajów postępowań dotyczy tylko przepisów regulujących postępowanie zwykłe, gdyż postępowania odrębne nie znajdą w tym wypadku zastosowania.

II. Prawomocne postanowienie orzekające co do istoty sprawy nie może być zmienione ani uchylone, chyba że przepis szczególny stanowi inaczej. Jednakże prawomocne postanowienie oddalające wniosek sąd może zmienić w razie zmiany okoliczności sprawy (art. 523 k.p.c.).

Prawomocność występuje w podwójnej roli - pozytywnej i negatywnej. ${ }^{4}$ Pozytywna rola prawomocności oznacza nakaz zawiązania $w$ przypadkach prejudycjalności, czego wyrazem jest art. 365 § 1 k.p.c., stanowiący, iż prawomocne orzeczenie wiąże nie tylko strony i sąd, który je wydał, lecz również inne sądy, organy państwowe i organy administracji publicznej, a w wypadkach w ustawie przewidzianych także inne osoby. Negatywna zaś funkcja jako ne bis in idem występuje w przypadkach ponownego wniesienia powództwa w tej samej sprawie, pomiędzy tymi samymi podmiotami prawnymi. W nauce prawa prawomocność dzieli się również na - formalną i materialną. Obie prawomocności pozostają ze sobą w ścisłym związku, stąd doktryna wyraża pogląd, że nie są to dwa rodzaje prawomocności, lecz dwa aspekty tego samego pojęcia. ${ }^{5}$ Wyrazem prawomocności materialnej jest art. 365 k.p.c., który stanowi, że orzeczenie prawomocne wiąże nie tylko strony i sąd, który je wydał, lecz również inne sądy oraz organy państwowe i organy administracji publicznej, w wypadkach w ustawie przewidzianych także inne osoby. Przepis ten określa granice podmiotowe prawomocności materialnej poprzez określenie - kogo wiąże prawomocne orzeczenie. Granice zaś przedmiotowe

3 W. Siedlecki, Zarys postępowania..., op. cit., s. 412.

4 F.L. Keller, Uber Litiscontestation und Urtheil, Zürich 1827, za: H.F. Gaul, M. Sawczuk, Obalanie prawomocnych orzeczeń w systemie procesu cywilnego RFN i PRL (na tle prawnoporównawczym), [w:] Z zagadnień cywilnego prawa materialnego i procesowego, M. Sawczuk (red.), Lublin 1988, s. 33. 
tej prawomocności określone są rozstrzygnięciem zawartym w prawomocnym orzeczeniu, a konkretnie granicami tego rozstrzygnięcia. ${ }^{6} \mathrm{~W}$ granicach prawomocności materialnej można i należy przyjmować, że dana sytuacja kształtuje się tak, jak zostało to przyjęte w orzeczeniu. Granice prawomocności materialnej są szersze i inaczej ukształtowane niż granice powagi rzeczy osądzonej. ${ }^{7}$

Każde orzeczenie może mieć prawomocność materialną, gdyż jest formalnie prawomocne. Nie każde jednak orzeczenie formalnie prawomocne jest zarazem materialnie prawomocne. Kodeks postępowania cywilnego przyznaje prawomocność formalną orzeczeniom w ogóle (a więc wyrokom, nakazom zapłaty, postanowieniom, wpisowi w k.w.), podczas gdy prawomocność materialną (res iudicata) mają tylko wyroki, a nie mają jej postanowienia, gdyż nie rozstrzygają istoty sporu. ${ }^{8}$ Jedyny wyjątek dotyczy postanowień merytorycznych zapadających w postępowaniu nieprocesowym, które pod względem skutków są zrównane z wyrokami w procesie cywilnym. Odmowa przyznania tym postanowieniom powagi rzeczy osądzonej pozostawałaby w sprzeczności z przyjętą przez kodeks zasadą jedności. ${ }^{9}$ Poglądy doktryny dzielą się na te, które odmawiają tym postanowieniom powagi rzeczy osądzonej, skoro można je zmienić lub uchylić nawet bez zmiany okoliczności ${ }^{10}$ i na te, które uważają, że fakt, iż prawomocne postanowienie może być zmienione lub uchylone, nie pozbawia go powagi rzeczy osądzonej, ${ }^{11}$ lecz stanowi pewien wyłom w tej powadze. ${ }^{12}$ W. Siedlecki ${ }^{13}$ stwierdza, że w postępowaniu nieprocesowym prawomocne postanowienia orzekające co do istoty sprawy korzystają z powagi rzeczy osądzonej z tym, że kodeks postępowania cywilnego wprowadza pewne wyjątki, które przewiduje art. 523 k.p.c. Natomiast B. Dobrzański wyraził zastrzeżenie, że istnieją pewne wyjątkowe przypadki, ale niekoniecznie wynikające z ustawy, lecz z istoty stosunku prawnego, w których postanowienia te nie korzystają z powagi rzeczy osądzonej. Dotyczy to również postanowień oddalających wniosek, które mogą być zmienione w miarę zmiany okoliczności sprawy, mają powagę rzeczy osądzonej dopóki stan faktyczny nie ulegnie zmianie. ${ }^{14}$

Związanie prawomocnym postanowieniem co do istoty sprawy zależy w postępowaniu nieprocesowym - inaczej niż w procesie (art. $365 \S 1$ ) - od

6 W. Broniewicz, Prawomocność orzeczeń w postępowaniu cywilnym, „Studia luridica” 1976, nr V, s.76.

7 A. Góra-Błaszczykowska, Orzeczenia w procesie cywilnym, Art. 316-366 KPC. Komentarz, s. 209.

8 Z. Fenichel, Podstawa powództwa, jej zmiana i związek z prawomocnością wyroku (dokończenie), PPC 1938, Nr $11-12$, s. 344 i nast.

9 K. Korzan, Skutki orzeczeń rozstrzygających sprawę co do istoty (prawomocność, wykonalność i skuteczność), Rej. 2005/4, s. 9-10.

10 Por. J. Krajewski, Postępowanie nieprocesowe (skrypt), Toruń 1973, s. 58; K. Korzan, Skutki orzeczeń..., op. cit., s. 9 in.

11 M. Sawczuk, Ponowne orzekanie w sprawie prawomocnie osądzonej, Warszawa 1975, s. 29; M. Lisiewski, Roszczenia zainteresowanego, który nie uczestniczył w postępowaniu na podstawie art. 44 k.p.n. (art. 467 projektu k.p.c.), Pal. 1963, nr 10, s. 7-8.

12 W. Broniewicz, Prawomocność..., op. cit., s. 79.

13 W. Siedlecki, Postępowanie..., op. cit., s. 405.

14 B. Dobrzański, Glosa do uchwały SN II CO 12/62, OSPiKA 1964, poz. 27. 
charakteru orzeczenia. W wypadku postanowień uwzględniających żądanie (pozytywnych, sankcjonujących, ustalających, kształtujących) związanie ma charakter bezwzględny, chyba że przepis szczególny dopuszcza uchylenie lub zmianę orzeczenia. ${ }^{15}$

Przepisami szczególnymi, o których mówi treść art. 523 k.p.c. jest cały oddział 3 rozdziału 1, działu 1, tytułu II - regulujący postępowanie w przedmiocie uchylenia postanowienia orzekającego uznanie za zmarkego. Przepisy te ograniczają zasadę stabilności prawomocnych postanowień in meritum wydawanych w postępowaniu niespornym i w ten sposób zapewniają znaczną elastyczność w zakresie transformacji postanowień o uznaniu za zmarłego. ${ }^{16}$

Unormowania tego postępowania umożliwiają uchylenie takiego postanowienia poza systemem środków zaskarżenia - przy zmianie stanu faktycznego, ale i na skutek zmiany stanu wiedzy sądu o stanie faktycznym sprawy. Głównym założeniem postępowania o uchylenie postanowienia o uznaniu za zmarłego jest ułatwienie uchylenia takiego postanowienia w sytuacji, gdy po uprawomocnieniu się okaże się, że osoba, którą uznano za zmarłą - żyje lub też zmarła w innej chwili niż oznaczona w orzeczeniu. ${ }^{17}$

III. Wspomniany oddział 3 regulujący postępowanie w zakresie uchylenia postanowienia orzekające uznanie za zmarłego wprowadza dwa tryby umożliwiające uchylenie tegoż orzeczenia. Pierwsze obejmuje przeprowadzenie całego postępowania dowodowego celem ustalenia, że osoba, która została uznana za zmarłą - pozostaje przy życiu, a zachodzi głównie w sytuacji, gdy osoba odnalazła się, ale nie może wziąc udziału w postępowaniu, a $\mathrm{z}$ wnioskiem wystąpi osoba zainteresowana lub sąd przeprowadzi postępowanie $\mathrm{z}$ urzędu, wzywając do udziału w sprawie uczestników postępowania, w którym zapadło postanowienie o uznaniu za zmarłego.

Drugi tryb stanowi specyfikę w zakresie obalania prawomocnych postanowień co do istoty sprawy, gdyż odbywa się bez jakiegokolwiek postępowania. Reguluje go tylko jeden artykuł - 543 k.p.c., stanowiący, iż osoba, którą uznano za zmarłą zjawi się osobiście w sądzie i wykaże swoją tożsamość, sąd niezwłocznie i bez dalszego postępowania uchyli postanowienie orzekające uznanie za zmarłego. $\mathrm{W}$ doktrynie tryb ten często nazywany jest uproszczonym, jednak $\mathrm{z}$ uwagi na istnienie $\mathrm{w}$ kodeksie postępowania cywilnego odrębnego rodzaju postępowania uproszczonego uregulowanego w księdze pierwszej - Proces, tytule VII, dziale

\footnotetext{
15 J. Gudowski, [w:] M. Jędrzejewska, K. Weitz, T. Ereciński, J. Gudowski, Kodeks postępowania cywilnego. Komentarz. Część pierwsza. Postępowanie rozpoznawcze. Część druga, Postępowanie zabezpieczające, Warszawa 2009 , Lex Polonica Online, kom. do art. 523 k.p.c.

16 Por. K. Lubiński, Prawomocność materialna orzeczeń w postępowaniu nieprocesowym, PiP 2003, nr 11, s. 55; A. Bartoszewicz, Postępowanie o uznanie za zmarłego i stwierdzenie zgonu, Warszawa 2007, s. 66.

17 K. Korzan, Postępowanie nieprocesowe - część szczegółowa, Katowice 1983, s. 121-122.
} 
VI w art. $505^{1}-505^{14}$ - wydaje się, iż bardziej właściwe będzie posługiwanie się określeniem przyjętym w tytule artykułu, tj. tryb przyśpieszony.

IV. Przepis art. 543 k.p.c. będący podstawą uchylenia postanowienia orzekającego uznanie za zmarłego bez przeprowadzenia postępowania dowodowego wprowadza dwie podstawowe przesłanki dla osoby pragnącej obalić prawomocne orzeczenie o uznaniu jej za zmarłą. Co istotne, przesłanki te muszą być spełnione kumulatywnie, a są to: 1) osobiste stawiennictwo w sądzie oraz 2) wykazanie swojej tożsamości.

Dalsze dwie przesłanki przewidziane są dla działania sądu w tym zakresie - czas uchylenia takiego postanowienia, określony jako - niezwłocznie oraz brak dalszego postępowania.

Przesłanka „zjawi się osobiście w sądzie” oznacza nic innego, jak osobiste stawiennictwo danej osoby, wobec której orzeczono, iż nie żyje. Nie jest możliwe stawiennictwo przez pełnomocnika procesowego, natomiast gdy osoba była ubezwłasnowolniona (całkowicie bądź częściowo) powinna stawić się ze swoim przedstawicielem, przy czym nie jest to wymóg konieczny, gdyż osoba taka nie składa żadnego wniosku o uchylenie danego orzeczenia, a sąd w takiej sytuacji działa $\mathrm{z}$ urzędu, sam zaś fakt pojawienia się osoby w sądzie jest tylko impulsem dla organu sądowego do podjęcia działania. Stąd też postępowanie w omawianym trybie jest wolne od opłaty sądowej (por. art. 23 pkt 1 u.k.s.c. ${ }^{18}$ ).

Jeżeli osoba uznana za zmarłą nie może stawić się osobiście w sądzie, sąd nie może dokonać uchylenia postanowienia o uznaniu za zmarłego w omawianym trybie, a będzie zobligowany przeprowadzić postępowanie dowodowe zgodnie $\mathrm{z}$ art. 542 k.p.c.

Drugą przesłanką jest wykazanie tożsamości przez osobę, która zjawiła się w sądzie i która chce uchylenia orzeczenia uznającego ją za nieżyjącą.

Tożsamość oznacza cechy, które stanowią o tym, kim dana osoba jest, czym różni się od innych. Na tak rozumianą tożsamość składa się nie tylko to, kim się jest obecnie, ale także to, kim się było, a nawet zamierzenia na przyszłość, wszystko to powoduje, że dana osoba różni się od innej. ${ }^{19}$

Tożsamość osoby fizycznej to jej indywidualizacja dokonywana na podstawie takich cech, jak:

1) imię i nazwisko - imię nadają dziecku osoby sprawujące władzę rodzicielską, nazwisko zaś zależy przede wszystkim od przynależności danej osoby do określonej rodziny, a jego nabycie lub zmiana związane są z wystąpieniem 
określonych zdarzeń prawnych, takich jak: urodzenie się dziecka, zawarcie małżeństwa, przysposobienie, zmiana nazwiska $\mathrm{w}$ trybie administracyjnym zgodnie z ustawą o zmianie imienia i nazwiska; ${ }^{20}$

2) miejsce zamieszkania - jest zawsze oznaczoną miejscowością. Definicję legalną miejscowości zawiera ustawa o urzędowych nazwach miejscowości i obiektów fizjograficznych, ${ }^{21}$ wskazująca, iż miejscowość to ,jednostka osadnicza lub inny obszar zabudowany odróżniający się od innych miejscowości odrębną nazwą, a przy jednakowej nazwie - odmiennym określeniem ich rodzaju" (art. 2 pkt 4 ustawy). Miejscem zamieszkania nie jest więc oznaczone mieszkanie, czyli tzw. adres osoby. Doktryna prawa cywilnego rozróżnia dwa rodzaje miejsca zamieszkania: domicilium voluntarium oraz domicilium necessarium.

Konstrukcję domicilium voluntarium reguluje art. 25 k.c. wskazujący, że miejscem zamieszkania osoby fizycznej jest miejscowość, w której osoba ta przebywa z zamiarem stałego pobytu. ${ }^{22}$ Zaś domicilium necessarium polega na uniezależnieniu miejsca zamieszkania osoby fizycznej od przebywania lub zamiaru stałego pobytu w określonej miejscowości, a dotyczy ona dzieci pozostających pod władzą rodzicielską lub osób pozostających pod opieką (art. 26 i 27 k.c.). Można mieć tylko jedno miejsce zamieszkania (art. 28 k.c.).

Od miejsca zamieszkania należy odróżnić zameldowanie na pobyt stały bądź czasowy, które należy do zakresu prawa administracyjnego, a uregulowane jest $\mathrm{w}$ ustawie o ewidencji ludności. ${ }^{23}$ Zgodnie $\mathrm{z}$ art. 24 - obywatel polski przebywający na terytorium Rzeczypospolitej Polskiej jest obowiązany wykonywać obowiązek meldunkowy określony w ustawie. Obowiązek meldunkowy polega na: 1) zameldowaniu się w miejscu pobytu stałego lub czasowego; 2) wymeldowaniu się z miejsca pobytu stałego lub czasowego. Zaś pobytem stałym jest zamieszkanie w określonejmiejscowościpod oznaczonymadresemzzamiarem stałegoprzebywania, a pobytem czasowym jest przebywanie bez zamiaru zmiany miejsca pobytu stałego w innej miejscowości pod oznaczonym adresem lub w tej samej miejscowości, lecz pod innym adresem (art. 25 ust. 1 i 2 ustawy). Obowiązek meldunkowy istnieje jednak do dnia 31.12.2013 r., gdyż od dnia 01.01.2014 r. obowiązek ten zostanie całkowicie zniesiony i nie będą już gromadzone daty zdarzeń z tym związanych. $\mathrm{Z}$ tym samym dniem nastąpi również likwidacja obowiązku prowadzenia rejestrów

Ustawa z dnia 17.10.2008 r., o zmianie imienia i nazwiska (Dz.U. Nr 220, poz. 1414).

Ustawa z dnia 29.08.2003 r., o urzędowych nazwach miejscowości i obiektów fizjograficznych (Dz.U. Nr 166, poz. 1612).

Jak przyjmuje się w nauce prawa, na tak rozumiane miejsce zamieszkania składają się dwa elementy: obiektywny (tzw. corpus) - czyli przebywanie w określonej miejscowości i subiektywny (tzw. animus) - zamiar stałego przebywaniu w danej miejscowości.

23 $01.01 .2013 \mathrm{r}$. 
mieszkańców oraz rejestrów zamieszkania cudzoziemców. Pod rządem wskazanej ustawy szczególnego znaczenia nabierze rejestr PESEL - centralny zbiór danych dotyczących obywateli polskich i cudzoziemców zamieszkujących na terenie RP - prowadzony przez ministra spraw wewnętrznych i administracji. Uprawnionymi do dokonywania rejestracji danych w rejestrze PESEL będą: kierownicy urzędów stanu cywilnego, organy gminy, wojewodowie oraz organy właściwe do wydawania paszportów.

3) ostatnią cechą jest wiek osoby niezbędny do oceny zdolności do czynności prawnych oraz zdolności do zawarcia małżeństwa. Wiek ustalany jest na podstawie daty urodzenia odnotowanej w akcie urodzenia.

Oprócz wyżej wskazanych cech można wskazać inne dodatkowe charakteryzujące daną osobę fizyczną. A są to: płeć, stan cywilny (w ujęciu wąskim jako status rodzinny, bądź szerokim jako stan osobisty), imiona czy też nazwiska rodziców, ale i wizerunek lub rysopis. ${ }^{24}$

Z pojęciem tożsamości wiąże się pojęcie dokumentu tożsamości. Dokument tożsamości to dowód osobisty i paszport, natomiast inne dokumenty, takie jak: prawo jazdy, legitymacja studencka, legitymacja pracownicza, ale i karta miejska ${ }^{25}$ - to dokumenty, na podstawie których można określić tożsamość danej osoby. Przepis art. 543 k.p.c. mówi o wykazaniu tożsamości, a nie przedstawieniu dokumentu tożsamości. Wykazanie tożsamości należy odróżnić od stwierdzenia tożsamości. Wykazać swoją tożsamość musi osoba zjawiająca się w sądzie, a sąd stwierdzając jej tożsamość (choć przepis o tym wprost nie stanowi) uchyli postanowienie o uznaniu jej za zmarłą. Identyfikacja takiej osoby powinna głównie ograniczać się do potwierdzenia jej imienia, nazwiska oraz wieku. Wskazywanie miejsca zamieszkania, w sytuacji gdy osoba wcześniej zaginęła, nie jest konieczne, z uwagi chociażby na odpadnięcie jednej z przesłanek - faktu przebywania osoby w danej miejscowości. Stąd też identyfikacja osoby, która zjawiła się w sądzie domagając się natychmiastowego uchylenia postanowienia o uznaniu jej za zmarłą, może nastąpić w każdy sposób, byleby wiarygodny dla sądu i wyłączający wszelkie wątpliwości. Pojęcie „wykazanie tożsamości” ma charakter subiektywno-obiektywny, gdyż oprócz tego, iż osoba uznana za zmarłą musi wykazać (jeśli chce skorzystać z trybu przyśpieszonego), iż to właśnie ona została uznana za nieżyjącą, to jednak oceny czy identyfikacja osoby została poczyniona ponad wszelką wątpliwość dokonuje organ sądowy, który musi mieć pewność, iż osoba stawająca jest tą, co do której wydano orzeczenie. Przekonanie sądu będzie miało głównie miejsce w sytuacji, gdy

24 Por. A. Kawałko, H. Witczak, Prawo cywilne - część ogólna, Warszawa 2010, s. 72-74.

25 Na karcie miejskiej zakodowany jest unikatowy numer nadawany przez system informatyczny. Pod tym numerem zapisane są informacje o jej właścicielu i historia użycia karty. Właściciel ma obowiązek uzupełnić kartę imieniem, nazwiskiem i numerem dokumentu tożsamości. Istnieją także karty imienne, które dodatkowo oprócz tych danych zawierają także zdjęcie jej posiadacza. 
osoba nie posiada dokumentu tożsamości, a potwierdzenie jej tożsamości nastąpi na podstawie twierdzeń świadka lub świadków, np. osób z kręgu rodziny uznanego za zmarłego.

V. Kolejne dwie przesłanki dotyczą działania sądu we wskazanym postępowaniu przyśpieszonym, mającym na celu uchylenie postanowienia o uznaniu za zmarłego. Sąd stwierdzając, iż osoba, która zjawiła się osobiście i wykazała swoją tożsamość nie przeprowadza żadnego postępowania dowodowego i na posiedzeniu niejawnym bez zbędnej zwłoki uchyla swoje orzeczenie. Kodeks postępowania cywilnego wiele razy używa zwrotu „niezwłocznie”, jednak go nie definiuje. Należy przyjąć, że termin ten nie oznacza - ,natychmiast”, lecz bez nieuzasadnionego odwlekania. Jest to termin realny, przy jego spełnieniu należy uwzględnić wiele okoliczności. Pojęcie to dotyczy działania organów sądowych, stąd należy przyjąć, iż jest to termin instrukcyjny.

Sądem właściwym miejscowo do orzekania o uchyleniu postanowienia w przedmiocie uznania za zmarłego jest sąd, który w pierwszej instancji orzekał uznanie za zmarłego (art. 540 k.p.c.), co koresponduje z treścią art. $508 \S 1$ zd. 1 k.p.c. wskazującego, że właściwość miejscowa sądu w postępowaniu nieprocesowym oznaczona jest co do zasady w przepisie szczególnym. Właściwość sądu określona w art. 540 k.p.c. jest właściwością wyłączną. Stąd też osoba stawająca osobiście w sądzie zgodnie z art. 543 k.p.c. powinna się zgłosić do sądu, który orzekał w I instancji o uznaniu za zmarłego. Możliwe jest jednak wyznaczenie przez sąd przełożony innego sądu, jeśli sąd właściwy nie może rozpoznać sprawy lub podjąć innej czynności albo gdy wymagają tego względy celowości (art. $508 \S 2$ k.p.c.). Ta ostatnia przesłanka stanie się aktualna w sytuacji, gdy osoba pozostająca przy życiu chce skorzystać z przyśpieszonego postępowania uregulowanego $\mathrm{w}$ art. 543 k.p.c., przy czym jej stawiennictwo w sądzie właściwym według art. 540 k.p.c. będzie niemożliwe lub co najmniej bardzo utrudnione - np. ze względu na wiek lub stan zdrowia. ${ }^{26}$

Właściwy rzeczowo jest sąd rejonowy (art. 507 k.p.c.), co jednak nie wyłącza na podstawie art. $18 \mathrm{w}$ zw. $\mathrm{z}$ art. $13 \S 2$ k.p.c. rozpoznania sprawy w pierwszej instancji przez sąd okręgowy.

W przedmiotowym postępowaniu orzeka sąd w składzie jednego sędziego (art. $47 \S 1 \mathrm{w}$ zw. z art. $13 \S 2$ k.p.c.), z tym że prezes sądu może zarządzić rozpoznanie sprawy w składzie trzech sędziów zawodowych ze względu na szczególną zawiłość lub precedensowy charakter sprawy (art. $47 \S 4 \mathrm{w}$ zw. $\mathrm{z}$ art. $13 \S 2$ k.p.c.).

Postanowienie uchylające orzeczenie o uznaniu za zmarłego wydane na posiedzeniu niejawnym zgodnie $\mathrm{z}$ art. $517 \mathrm{w}$ zw. $\mathrm{z}$ art. $357 \S 2$ k.p.c. powinno 
być doręczone wraz $\mathrm{z}$ uzasadnieniem uczestnikom poprzednio toczącego się postępowania o uznaniu za zmarłego oraz osobie, która zjawiła się w sądzie i wykazała swoją tożsamość, a co za tym idzie fakt, iż żyje.

$\mathrm{Na}$ postanowienie sądu uchylające postanowienie o uznaniu za zmarłego $\mathrm{w}$ trybie przyśpieszonym przysługuje apelacja uczestnikom postępowania i osobie uznanej za zmarłą (art. 518 k.p.c.). Poza tym od wydanego przez sąd drugiej instancji postanowienia co do istoty sprawy oraz od postanowienia w przedmiocie odrzucenia wniosku i umorzenia postępowania kończących postępowanie w sprawie - w sprawach z zakresu prawa osobowego (a więc sprawach dotyczących uznania za zmarłego) - przysługuje skarga kasacyjna do Sądu Najwyższego, chyba że przepis szczególny stanowi inaczej (art. $519^{1} \S 1$ k.p.c.).

Zgodnie z art. $519^{2} \S 1$ k.p.c. można żądać stwierdzenia niezgodności z prawem prawomocnego postanowienia co do istoty sprawy sądu drugiej instancji kończącego postępowanie $\mathrm{w}$ sprawie, jeżeli przez jego wydanie stronie została wyrządzona szkoda, a zmiana lub uchylenie tego postanowienia w drodze przysługujących stronie środków prawnych nie było i nie jest możliwe. Jednak w postępowaniu nieprocesowym $\mathrm{w}$ znacznie szerszym zakresie niż $\mathrm{w}$ procesie możliwa jest zmiana oraz uchylenie prawomocnych postanowień co do istoty sprawy, co ogranicza możliwość korzystania ze skargi o stwierdzenie niezgodności z prawem prawomocnego postanowienia co do istoty sprawy sądu II instancji kończącego postępowanie w sprawie. Takim właśnie przepisem jest art. 543 k.p.c., stąd też osobie uznanej za zmarłą nie przysługuje możliwość wniesienia przedmiotowej skargi.

W postępowaniu nieprocesowym wznowienie postępowania nie jest dopuszczalne, gdy postanowienie co do istoty sprawy kończące postępowanie może być zmienione lub uchylone na podstawie innych przepisów (art. 524 k.p.c.). Dotyczy to dwóch grup orzeczeń: 1) postanowienia oddalające wniosek (o treści negatywnej), które - zgodnie z ogólnym przepisem art. 523 k.p.c. - sąd może zmienić zawsze, ilekroć dojdzie do zmiany okoliczności sprawy. Należy jednak przyjąć, że postanowienie oddalające wniosek można wzruszyć w drodze wznowienia postępowania, jeśli nie nastąpiła zmiana okoliczności, ale zachodzą przyczyny wznowienia, np. uczestnik był pozbawiony możliwości działania; ${ }^{27} 2$ ) postanowienia co do meritum wydane w sprawach, w których przepis szczególny pozwala na ich zmianę lub uchylenie, a więc omawiany art. 543 k.p.c. Jednak powielając prawidłowy sposób rozumowania przyjęty przez Sąd Najwyższy w uchwale z dnia 22.10 .1968 r., ${ }^{28}$ należy uznać, że jeżeli przepisy art. $539-543$ k.p.c.

\footnotetext{
27 Por. uzasadnienie uchwały SN z 21.04.1994 r., III CZP 40/94, OSNCP 1994, nr 11, poz. 210 z glosą T. Felskiego, Pal. 1995, nr 3-4, s. 256.

28 Uchwała z dnia 22.10.1968 r. III CZP 78/68, OSNCP 1969/6 poz. 105.
} 
nie przewidują trybu, w którym orzeczenie o uznaniu za zmarłego mogłoby być - w określonej sytuacji - uchylone lub zmienione, uzasadnione jest wznowienie postępowania na zasadach określonych $\mathrm{w}$ art. 524 k.p.c. ${ }^{29}$

Zgodnie $\mathrm{z}$ prawem o aktach stanu cywilnego ${ }^{30} \mathrm{w}$ razie uznania za zmarłego $\mathrm{w}$ postępowaniu sądowym organ sądowy przekazuje odpis prawomocnego orzeczenia o uznaniu za zmarłego do urzędu stanu cywilnego właściwego dla dzielnicy Śródmieście miasta stołecznego Warszawa, stanowiące podstawę wpisu do ksiąg stanu cywilnego (art. 10 ust. $3 \mathrm{i}$ art. 26). Tak samo powinien postąpić organ sądowy, gdy dokona uchylenia postanowienia o uznaniu za zmarłego w trybie przyśpieszonym.

VI. Na skutek uchylenia postanowienia o uznaniu za zmarłego dana osoba odzyskuje prawa osobiste oraz ma roszczenie o wydanie spadku. W sprawach małżeństwa tworzy się taka sytuacja, że jeśli drugi małżonek nie zawarł drugiego małżeństwa - to pierwsze jest ważne, ale jeśli drugi małżonek zawarł drugie małżeństwo, to co do zasady nowy związek małżeński nie może być unieważniony. Wyjątkowo drugi związek jest nieważny jako bigamiczny, jeżeli w chwili zawarcia związku małżeńskiego obaj małżonkowie wiedzieli, że małżonek uznany za zmarłego pozostaje przy życiu, tzn. byli w złej wierze.

Artykuł 13 Kodeksu rodzinnego i opiekuńczego stanowi o zakazie zawarcia małżeństwa dla osoby, która już w takim związku istnieje. Samo domniemanie śmierci małżonka nie zwalnia $\mathrm{w}$ tym wypadku $\mathrm{z}$ tego zakazu, konieczne jest faktyczne i prawne uznanie drugiego małżonka za zmarłego. Jeżeli po uznaniu jednego z małżonków za zmarłego drugi małżonek zawarł nowy związek małżeński, związek ten nie może być unieważniony z tego powodu, że małżonek uznany za zmarłego żyje albo że jego śmierć nastąpiła w innej chwili aniżeli chwila oznaczona w orzeczeniu o uznaniu za zmarłego (art. $55 \S 2$ k.r.o.).

Jeżeli jedno $\mathrm{z}$ małżonków uznane za zmarłe w rzeczywistości żyje, to jego małżeństwo trwa nadal i obowiązuje go zakaz przewidziany w art. $13 \S 1$ k.r.o., aż do momentu, gdy to małżeństwo ustaje. Ustaje zaś na skutek bądź śmierci drugiego $\mathrm{z}$ małżonków, bądź zawarcia przez niego drugiego małżeństwa w warunkach wynikających z art. $55 \S 2 \mathrm{zd}$. 1 (tzn. jeśli to drugie małżeństwo nie może być unieważnione). $\mathrm{W}$ tej ostatniej sytuacji jednemu $\mathrm{z}$ małżonków uznanemu za zmarłego nie wolno jednak zawrzeć drugiego małżeństwa z powołaniem się na domniemanie ustania jego pierwszego małżeństwa. ${ }^{31}$

Postanowienie SN z dnia 26.06.2002 r., III CKN 898/2000, OSNC 2003/6 poz. 89.

Ustawa z dnia 29.09.1986 r. Prawo o aktach stanu cywilnego (tekst jedn. z 2011 r. Dz.U. Nr 212, poz. 1264).

Orzeczenie SN z dnia 8.07.1969 r., II CR 100/69, OSNCP 1970, nr 4, poz. 73. 
Jeżeli jednak w chwili zawarcia nowego związku małżeńskiego strony wiedziały, że małżonek uznany za zmarłego żyje, wtedy jest możliwe unieważnienie tego drugiego małżeństwa na podstawie złej wiary „nowych” małżonków. W razie uznania jednego z małżonków za zmarłego domniemywa się, że małżeństwo ustało $\mathrm{z}$ chwilą, która w orzeczeniu o uznanie za zmarłego została oznaczona jako chwila jego śmierci. A zatem $z$ domniemania śmierci wynika domniemanie ustania związku małżeńskiego osoby uznanej za zmarłą z chwilą śmierci oznaczoną w postanowieniu o uznaniu za zmarłego. Jednakże orzeczenie to samo przez się nie przekreśla bytu prawnego związku małżeńskiego zaginionego. Wywołuje ono bowiem wszystkie skutki prawne śmierci z wyjątkiem rozwiązania małżeństwa osoby uznanej za zmarłą z pozostałym przy życiu małżonkiem. Uzasadnione jest to faktem, że uznanie jednego z małżonków za zmarłego nie powoduje samo przez się ustania małżeństwa, a stwarza jedynie domniemanie jego ustania. Pierwsze małżeństwo nie rozwiązuje się przez uznanie współmałżonka zaginionego za zmarłego. Skutek ten zostaje osiągnięty dopiero $\mathrm{z}$ chwilą zawarcia kolejnego związku małżeńskiego. $\mathrm{W}$ tej sytuacji to od małżonka zależy, czy chce pierwszy związek rozwiązać - zawierając drugie małżeństwo, czy nie zawierając kolejnego małżeństwa utrzyma dotychczasowe. Dlatego, broniąc trwałości związku małżeńskiego, ustawodawca przyjął obronę drugiego małżeństwa.

VII. Reasumując należy stwierdzić, iż wskazany tryb uchylenia prawomocnego orzeczenia stanowi specyfikę w kodeksie postępowania cywilnego. Odbywa się bez przeprowadzania postępowania dowodowego, nie pobiera się opłaty sądowej od tego typu postępowania, sąd działa $\mathrm{z}$ urzędu niezwłocznie uchylając swoje postanowienie, a co istotne tryb ten wymaga bezwzględnej obecności osoby uznanej za zmarłą i wykazania swojej tożsamości w sposób nie budzący wątpliwości dla organu sądowego. Sama zaś identyfikacja osoby fizycznej, której byt zdolności prawnej został zakończony, wystarczy, że będzie polegała na wykazaniu swojego imienia, nazwiska i wieku. Poza tym na skutek uchylenia postanowienia o uznaniu za zmarłego dana osoba odzyskuje prawa osobiste oraz ma roszczenie o wydanie spadku, a w sprawach małżeństwa stabilizuje się sytuacja małżonków, ponieważ - gdy drugi małżonek nie zawarł drugiego małżeństwa - to pierwsze jest ważne, ale jeśli drugi małżonek zawarł drugie małżeństwo, to co do zasady nowy związek małżeński nie może być unieważniony. 


\section{BIBLIOGRAFIA}

1. Bartoszewicz A., Postępowanie o uznanie za zmarłego i stwierdzenie zgonu, Warszawa 2007.

2. Broniewicz W., Prawomocność orzeczeń w postępowaniu cywilnym, „Studia Iuridica” 1976, nr V.

3. Dobrzański B., [w:] Dobrzański B., Lisiewski M., Resich Z., Siedlecki W., Kodeks postępowania cywilnego. Komentarz, Resich Z., Siedlecki W. (red.), Warszawa 1969.

4. Dobrzański B., Glosa do uchwały SN II CO 12/62, OSPiKA 1964, poz. 27.

5. Fenichel Z., Podstawa powództwa, jej zmiana i związek z prawomocnością wyroku (dokończenie), PPC 1938, Nr 11-12.

6. Góra-Błaszczykowska A., Orzeczenia w procesie cywilnym, Art. 316-366 KPC. Komentarz.

7. Gudowski J, [w:] Jędrzejewska M., Weitz K., Ereciński T., Gudowski J., Kodeks postępowania cywilnego. Komentarz. Część pierwsza. Postępowanie rozpoznawcze. Część druga. Postępowanie zabezpieczające, Warszawa 2009, Lex Polonica Online, kom. do art. 523 k.p.c.

8. Keller F.L., Uber Litiscontestationund Urtheil, Zürich 1827, [za:] Gaul H.F., Sawczuk M., Obalanie prawomocnych orzeczeń w systemie procesu cywilnego RFN i PRL (na tle prawnoporównawczym) [w:] Z zagadnień cywilnego prawa materialnego i procesowego, Sawczuk M. (red.), Lublin 1988.

9. Korzan K., Istota $\mathrm{i}$ charakter orzeczeń wydawanych $\mathrm{w}$ postępowaniu cywilnym (studium teoretyczne), [w:] M. Jędzrejewska, T Ereciński, Studia z prawa postępowanie cywilnego. Księga pamiątkowa ku czci Z. Resicha, Warszawa 1985.

10. Korzan K., Postępowanie nieprocesowe - część szczegółowa, Katowice 1983.

11. Korzan K., Skutki orzeczeń rozstrzygających sprawę co do istoty (prawomocność, wykonalność i skuteczność), Rej. 2005, nr 4.

12. Krajewski J., Postępowanie nieprocesowe (skrypt), Torun 1973.

13. Lisiewski M., Roszczenia zainteresowanego, który nie uczestniczył w postępowaniu na podstawie art. 44 k.p.n. (art. 467 projektu k.p.c.), Pal. 1963, nr 10.

14. Lubiński K., Prawomocność materialna orzeczeń w postępowaniu nieprocesowym, PiP 2003, nr 11.

15. Resich Z., [w:] Jodłowski J., Resich Z., Postępowanie cywilne, Warszawa 1979.

16. Sawczuk M., Ponowne orzekanie w sprawie prawomocnie osądzonej, Warszawa 1975.

17. Siedlecki W., [w:] System prawa procesowego cywilnego. Postępowanie rozpoznawcze przed sądami pierwszej instancji, t. II, pod red. Z. Resicha, Wrocław-Warszawa-Kraków-Gdańsk-Lódź 1987.

18. Siedlecki W., Zarys postępowania cywilnego, Warszawa 1968.

19. Ustawa z dnia 29.09.1986 r. Prawo o aktach stanu cywilnego (tekst jedn. Dz.U. z 2011 r. Nr 212, poz. 1264).

20. Ustawa z dnia 29.08.2003 r., o urzędowych nazwach miejscowości i obiektów fizjograficznych (Dz.U. Nr 166, poz. 1612).

21. Ustawa z dnia 28.07.2005 r., o kosztach sądowych w sprawach cywilnych (tekst jedn. Dz.U. Nr 90, poz. 594). 
22. Ustawa z dnia 17.10.2008 r., o zmianie imienia i nazwiska (Dz.U. Nr 220, poz. 1414).

23. Ustawa z dnia 24.09.2010 r., o ewidencji ludności (Dz.U. Nr 217, poz. 1427).

24. Uchwała z dnia 22.10.1968 r., III CZP 78/68, OSNCP 1969/6, poz. 105.

25. Orzeczenie SN z dnia 8.07.1969 r., II CR 100/69, OSNCP 1970, nr 4, poz. 73.

26. Uzasadnienie uchwały SN z 21.04.1994 r., III CZP 40/94, OSNCP 1994, nr 11, poz. 210 z glosą T. Felskiego, Pal. 1995, nr 3-4.

27. Postanowienie SN z dnia 26.06.2002 r., III CKN 898/2000, OSNC 2003/6 poz. 89.

28. Wyrok WSA z dnia 3.03.2009 r., sygn. akt II S.A./Wa1495/08. 


\section{THE PROCEDURE OF OVERTURNING DECISIONS DECLARING A PERSON LEGALLY DEAD IN AN ACCELERATED MANNER}

The aim of this paper is to present a specific, accelerated, procedure of overturning valid judgments in non-litigious proceedings, referring to decisions declaring a person legally dead. The procedure includes certain particular features: it does not require the hearing of evidence, no court fees are collected, the decision is overturned immediately ex officio, and most importantly, the procedure requires the unconditional presence of a person whose death was declared, who is obliged to confirm his or her identity in a way which raises no concerns to the court. Confirmation of identity may include only presenting proof of one's name, surname and age.

Key words: overturning valid judgments, decisions declaring a person legally dead, unconditional presence of a person whose death was declared, who is obliged to confirm his or her identity 